\title{
ANALISIS KESULITAN BELAJAR MATEMATIKA KELAS V SD NEGERI 25 RAJANG BEGANTUNG II
}

\author{
Andri $^{1}$, Dwi Cahyadi Wibowo ${ }^{2}$, Yofa Agia $^{3}$ \\ 1,2,3 STKIP Persada Khatulistiwa sintang \\ e-mail: ${ }^{1}$ andry tkr@yahoo.com ${ }^{2}$ dwicahyadiwibowo@gmail.com , \\ yofaargia56@gmail.com
}

\begin{abstract}
This study is meant to describe: (a) Difficulty in learning mathematics in fifth grade, (b) the reasons behind those difficulty faced by the students, (c) Teachers' efforts to overcome the difficulties of learning mathematics in fifth grade, (d) Large The level of difficulty in learning mathematics experienced by fifth graders. This type of research is a type of qualitative research. Difficulties experienced by students are difficulty understanding concepts, difficulties in skills, and difficulties in solving problems Data collection methods used were interview and test methods. Research shows that: (1) Difficulty understanding concepts, difficulties in skills, and difficulties in solving problems. (2) The causes of those difficulty in learning comes from social, emotional, and intellectual of students themselves. (3) Teacher's efforts to overcome learning difficulties by holding remedial. (4) The level of learning difficulties of students included in the category is very difficult. It is hoped that the teacher can overcome student learning difficulties. So that students' difficulties in learning mathematics are slightly overcome
\end{abstract}

Keyword: Difficulty, Learning, Mathematics

Abstrak. Penelitian ini bertujuan untuk mendeskripsikan: (a) Kesulitan belajar matematika siswa kelas V, (b) Faktor penyebab kesulitan belajar matematika siswa kelas V, (c) Upaya guru untuk mengatasi kesulitan belajar matematika kelas $V$, (d) Tingkat kesulitan dalam pembelajaran matematika yang dialami siswa kelas $V$. Jenis dalam penelitian ini adalah jenis penelitian kualitatif. Metode pengumpulan data yang digunakan adalah metode wawancara dan tes. Hasil Penelitian menunjukkan bahwa: (1) siswa kesulitan memahami konsep, kesulitan dalam keterampilan, dan kesulitan memecahkan masalah, (2) Faktor-faktor yang menyebabkan peserta didik mengalami kesulitan dalam belajar yaitu faktor sosial, emosional, dan intelektual. (3) Upaya guru mengatasi kesulitan belajar dengan mengadakan remidi. (4) Tingkat kesulitan belajar siswa termasuk dalam kategori sangat sulit. Diharapkan guru dapat mengatasi kesulitan belajar siswa. Sehingga kesulitan siswa pada pembelajaran matematika sedikit teratasi.

Kata Kunci: Kesulitan, Belajar, Matematika 


\section{PENDAHULUAN}

Ilmu matematika merupakan ilmu yang dipelajari peserta didik mulai dari tingkat sekolah dasar, tingkat menengah sampai universitas yang penekanannya pada pemahaman konsep dan struktur-struktur. Walaupun matematika beroperasi berdasarkan aturan-aturan (rules) yang perlu dipelajari, tetapi kegiatan belajar ditujukan lebih dari hanya dapat melakukan operasi matematika sesuai dengan aturan-aturan matematika yang diungkapkan dalam bahasabahasa matematika (Jamaris, 2015:177).

Matematika digunakan secara luas dalam berbagai bidang kehidupan, diharapkan pembelajaran matematika di kelas bisa dikemas sedemikian rupa sehingga siswa bisa belajar secara optimal dan pada akhirnya mendapatkan hasil yang maksimal. Untuk itulah, diperlukan berbagai upaya atau usaha para pendidik matematika, bagaimana agar pembelajaran matematika bisa diserap dengan mudah oleh siswa. Prinsip-prinsip matematika banyak digunakan dalam beberapa alat yang dapat membantu manusia dalam kehidupan sehari-harinya, seperti kalkulator, komputer, dan lain-lain.

Bagi sebagian orang, matematika dianggap sebagai kegiatan yang dilakukan dalam menjumlah, mengurang, dan membagi atau kegiatan yang berkaitan penyelesaian masalah hitungan yang disajikan dalam bentuk soal. Pada hakikatnya, matematika meliputi bidang yang lebih luas daripada aplikasi angka, matematika juga mencakup hal-hal yang berkaitan dengan pengukuran, uang, pola, geometri, statistik, dan pemecahan masalah. Sebagian anak di sekolah dasar mengalami kesulitan belajar matematika, sementara anak yang lainnya belajar matematika dengan mudah tanpa mengalami kesulitan (Jamaris, 2015:186).

Maka, kesulitan belajar matematika dapat diartikan sebagai suatu gangguan dari dalam diri yang dialami peserta didik yang menyebabkan peserta didik tidak dapat mengikuti pembelajaran tentang bilangan, termasuk pembelajaran umum didalamnya yang terdapat penjumlahan, pengurangan, perkalian, dan pembagian dengan efektif dan wajar. Karakteristik siswa yang mengalami kesulitan belajar matematika berbeda antara peserta didik satu dengan peserta didik yang lain. Sehingga, upaya penanganan siswa yang berkesulitan belajar matematika yang diberikan oleh guru berbeda antara masingmasing peserta didik yang mengalami kesulitan belajar. Kesulitan belajar matematika yang dialami peserta didik harus segera ditangani dengan tepat, agar peserta didik dapat belajar matematika dengan baik. Hal ini dikarenakan matematika merupakan cabang ilmu pengetahuan yang penting untuk dipelajari.

\section{METODE}

Pada penelitian digunakan pendekatan kualitatif. Penelitian ini bertujuan untuk mengetahui jenis kesulitan matematika yang dialami siswa, penyebab kesulitan pembelajaran matematika, serta mengungkapkan upaya yang dapat dilakukan untuk mengatasi kesulitan pembelajaran di kelas IV Sekolah Dasar. Penelitian ini 
menggunakan metode penelitian deskriptif kualitatif.

Penelitian kualitatif adalah penelitian yang bermaksud memahami fenomena tentang apa yang dialami oleh subjek penelitian misalnya perilaku, persepsi, motivasi, tindakan, dan lain-lain, secara holistik, dan dengan cara deskripsi dalam bentuk kata-kata dan bahasa, pada suatu konteks khusus yang alamiah dengan memanfaatkan berbagai metode ilmiah.

Penelitian ini dilakukan di SDN 25 Rajang Begantung 2 Desa Kunyai Kecamatan Sintang Kabupaten Sintang. Waktu Penelitian dilakukan pada bulan Agustus 2019.

Subjek dalam penelitian ini yaitu guru kelas V, guru dipilih karena guru berperan besar dalam pembelajaran di sekolah. Peneliti melakukan wawancara dengan guru kelas $\mathrm{V}$ untuk mengetahui jenis kesulitan belajar matematika serta upaya yang telah dilakukan untuk mengatasi kesulitan belajar matematika. Selanjutnya subjek penelitian ini adalah siswa kelas V SDN 25 Rajang Begantung II yang berjumlah 10 orang siswa.

Teknik pengumpulan data menggunakan wawancara dan tes. Sedangkan teknik analisis data yang digunakan adalah dengan menggunakan analisis data kualitatif. Analisis data dalam suatu penilitian merupakan pokok utama dalam sebuah penilitian karena dengan melakukan analisis akan dapat diperoleh hasil dari apa saja kesulitan belajar matematika berdasarkan kelompoknya melalui wawancara dan teknik tes. Peniliti menguji kredibilitas data dengan triangulasi teknik. Triangulasi teknik berarti peneliti menggunakan teknik pengumpulan data yang berbeda-beda untuk mendapatkan data dengan sumber yang sama.

\section{HASIL DAN PEMBAHASAN}

\section{Kesulitan Belajar Matematika}

a. Kesulitan Memahami Konsep

Konsep menunjuk pada pemahaman dasar siswa. Dalam penelitian ini, kesulitan memahami konsep yang dialami siswa yaitu kesulitan pada konsep mengubah pecahan campuran menjadi pecahan biasa, serta penjumlahan dan perkalian pecahan. Kesulitan tersebut ditunjukkan ketika siswa tidak dapat mengerjakan soal tentang mengubah pecahan campuran menjadi pecahan biasa, serta penjumlahan dan perkalian pecahan. Kondisi tersebut seperti yang ditemukan dalam penelitian Jamal (2014:34) tentang analisis kesulitan belajar matematika dengan kesimpulan bahwa kesulitan siswa pada materi dikarenakan kurangnya pemahaman siswa dalam memahami konsep dan sering salah menggunakan rumus dalam menyelesaikan soal.

b. Kesulitan Keterampilan Berhitung

Keterampilan menunjuk pada sesuatu yang dilakukan seseorang. Jenis keterampilan matematika adalah proses dalam menggunakan operasi dalam penjumlahan, pengurangan, perkalian, dan pembagian. Kesulitan dalam operasi hitung dapat terjadi karena siswa melakukan kesalahan dalam mengoperasikan angka secara tidak benar. Kesalahan 
mengoperasikan angka ditemukan peneliti ketika mengerjakan soal materi pecahan, kesalahan tersebut membuat siswa tidak dapat menjawab dengan benar. Sesuai pendapat Jamaris (2015:188) bahwa kesulitan yang dialami anak yang kesulitan belajar matematika salah satunya adalah kelemahan dalam berhitung yang disebabkan salah membaca simbol dan mengoperasikan angka secara tidak benar.

Kesulitan siswa dalam keterampilan hitung juga disebabkan karena penguasaan kemampuan dasar berhitung seperti penjumlahan, pengurangan, perkalian, dan pembagian yang masih kurang di kelas IV. Hal tersebut diduga karena siswa tidak memahami hubungan antara satuan, puluhan, dan ribuan sehingga siswa tidak mampu menggunakan operasi matematika dengan tepat seperti yang dipaparkan Lawrence Mundia (2012). Kesulitan tersebut sebaiknya menjadi perhatian lebih bagi guru agar kesulitan siswa tidak berlanjut sehingga siswa dapat mencapai hasil belajar dengan baik. Selain itu, siswa juga kesulitan dalam keterampilan menghitung karena tidak teliti ketika menghitung sesuai dengan pendapat Runtukahu dan kandou (2014) bahwa siswa yang mengalami kesulitan belajar matematika sering melakukan kekeliruan dalam berhitung.

c. Kesulitan Memecahkan Masalah Pemecahan masalah adalah aplikasi dari konsep dan keterampilan. Pengembangan indikator dari pemecahan masalah ditunjukkan dengan siswa tidak melanjutkan pekerjaan dalam menyelesaikan soal. Hasil analisis kesulitan memecahkan masalah pada soal cerita menunjukkan bahwa siswa tidak mampu memaknai kalimat pada soal cerita dan tidak menentukan langkah pemecahan masalah dengan tepat sehingga tidak dapat menyelesaikan soal dengan benar. Contoh kasus yang ditemukan adalah siswa tidak mengerjakan soal pecahan sesuai dengan informasi yang ada pada soal dan tidak mengerjakan soal dengan langkah yang benar. Sebagaimana dikatakan Jamaris (2015:188) bahwa anak yang kesulitan belajar matematika mempunyai ciri pemahaman bahasa matematika yang kurang.

Kurangnya pemahaman tersebut mengakibatkan siswa mengalami kesulitan dalam membuat hubungan-hubungan yang bermakna matematika. Seperti yang terjadi dalam memecahkan masalah hitungan soal yang disajikan dalam bentuk cerita. Berdasarkan teori dan hasil penelitian ditemukan proposisi bahwa jenis kesulitan belajar matematika yang dialami siswa adalah kesulitan memahami konsep pecahan, kesulitan dalam menghitung pada bilangan pecahan, dan kesulitan memecahkan masalah pada soal cerita.

\section{Faktor Penyebab Kesulitan Belajar Matematika}

Setelah ditemukan jenis kesulitan belajar yang dialami siswa, selanjutnya akan membahas tentang faktor penyebab kesulitan belajar matematika. Analisis faktor penyebab kesulitan belajar matematika siswa dilaksanakan dengan menganalisis hasil wawancara. Setelah dilakukan 
analisis dapat diketahui bahwa penyebab kesulitan belajar siswa disebabkan oleh faktor internal dan faktor eksternal. Untuk mengetahui masing-masing faktor penyebab kesulitan belajar matematika dijelaskan sebagai berikut.

\section{a. Faktor Penyebab Kesulitan Secara Internal}

1) Sikap dalam Belajar

Hasil analisis faktor penyebab kesulitan secara internal sesuai yang diungkapkan oleh Slameto (2010:188) bahwa faktor yang mempengaruhi hasil belajar adalah sikap. Sikap positif terhadap suatu mata pelajaran adalah awal yang baik untuk proses pembelajaran. Sebaliknya sikap negatif terhadap mata pelajaran akan berpotensi menimbulkan kesulitan belajar atau membuat hasil belajar yang kurang maksimal.

Dari pernyataan siswa dalam hasil wawancara, siswa tidak menyukai pelajaran matematika dan mempunyai sikap negatif terhadap pembelajaran matematika sehingga siswa tidak mengikuti pembelajaran dengan baik. Sikap tersebut ditunjukkan dengan bertindak gaduh dan tidak memperhatikan ketika pembelajaran matematika berlangsung. Selain itu, sikap negatif juga ditunjukkan dengan siswa yang tidak antusias, siswa cenderung tidak aktif dalam pembelajaran.

Sikap siswa pada pembelajaran matematika dipengaruhi oleh sikap guru yang mengajar. Guru yang mengajar dengan menyenangkan dan memberi perhatian akan menimbulkan sikap positif bagi siswa sehingga siswa mengikuti pembelajaran dengan baik. Hal ini sesuai dengan hasil penelitian Paul Mutodi (2014) bahwa faktor psikologi mempengaruhi pencapaian siswa dan praktik umum mereka. Untuk itu, guru perlu menanamkan sikap positif kepada siswa melalui pembelajaran matematika yang menyenangkan, serta memberikan keyakinan pada siswa akan kebermanfaatan pelajaran matematika sehingga diharapkan muncul sikap positif pada pelajaran matematika.

2) Motivasi Belajar

Motivasi berfungsi mengarahkan perbuatan siswa dalam belajar. Hasil analisis menunjukkan bahwa motivasi belajar siswa masih rendah. Siswa tidak mempersiapkan alat tulis dan buku pelajaran matematika, ketika pembelajaran matematika dimulai. Siswa juga tidak mempelajari kembali materi yang telah diajarkan disekolah ketika dirumah dan siswa tidak belajar matematika ketika tidak ada ulangan. Rendahnya motivasi siswa juga mengakibatkan siswa tidak antusias mengikuti pembelajaran matematika sehingga menimbulkan kesulitan belajar matematika. Hal ini sesuai dengan pendapat dari Ahmadi dan Supriyono (Tyas Ni'mah 2016) bahwa siswa yang motivasinya lemah tampak acuh tak acuh, mudah putus asa dan perhatiannya tidak tertuju pada pelajaran akibatnya banyak mengalami kesulitan belajar.

Motivasi siswa yang rendah diduga karena motivasi dari dalam diri siswa tidak ditanamkan dengan baik oleh orang tua 
dirumah. Orang tua yang tidak memberikan perhatian secara maksimal akan berdampak pada rendahnya motivasi belajar siswa di sekolah. Motivasi dari dalam diri siswa sendiri atau motivasi instrinsik mempengaruhi hasil belajar siswa. Pemberian motivasi telah dilakukan oleh guru secara lisan dengan memberikan contoh-contoh sikap yang perlu ditiru agar berhasil dalam belajar. Untuk itu, guru dan orang tua perlu memberi perhatian lebih serta bekerja sama untuk selalu meningkatkan motivasi siswa sehingga siswa tidak mengalami kesulitan belajar matematika.

3) Kesehatan Tubuh

Kesulitan belajar matematika siswa dapat ditimbulkan oleh faktor fisiologis. Hasil analisis menunjukkan bahwa tidak semua siswa mengalami kesulitan belajar matematika yang disebabkan masalah kesehatan. Namun terdapat beberapa siswa yang sering tidak masuk kelas karena sakit sehingga berdampak pada tertinggalnya materi pelajaran matematika.

Masalah kesehatan yang sering muncul dan berdampak pada siswa adalah kondisi fisik siswa yang kurang sehat. Siswa tidak konsentrasi belajar dan mengantuk ketika pelajaran matematika mengindikasikan kondisi fisik tidak dalam keadaan yang optimal. Keadaan tubuh yang tidak optimal mempengaruhi penerimaan siswa terhadap informasi yang disampaikan. Hal ini sesuai dengan penelitian Guntoro (2014) bahwa tingkat kebugaran jasmani mempengaruhi prestasi belajar siswa.

Secara umum, tidak banyak siswa yang mengalami masalah kesehatan. Namun faktor kesehatan tetap perlu menjadi perhatian, guru dapat mengarahkan siswa untuk menjaga kesehatan. Tidak cukup sampai disitu, sebaiknya orang tua juga menjaga pola makan serta mengatur jam istirahat anak sehingga mereka selalu dalam keadaan tubuh yang sehat dan dapat menyerap pelajaran matematika dengan baik.

4) Kemampuan Penginderaan

Dari hasil analisis yang dilakukan ditemukan satu siswa yang mengalami gangguan pada pengindraan. Yaitu tidak dapat melihat jauh atau menderita rabun jauh. Gangguan penglihatan yang dialami siswa dapat mengurangi daya serap informasi yang disampaikan oleh guru. Hal ini seperti yang disampaikan oleh Muhibbin Syah (Tyas, 2016) bahwa terganggunya alat pendengaran dan alat penglihatan menjadi faktor internal kesulitan belajar siswa.

Guru sudah mengurangi ganggunan kemampuan pengindraan siswa dengan memindahkan tempat duduk siswa di bangku paling depan. Ada baiknya pihak sekolah bekerja sama dengan ahli kesehatan untuk melakukan pemeriksaan pada kemampuan pengindraan siswa, orang tua juga perlu memperhatikan dengan baik kemampuan pengindraan siswa khususnya pendengaran dan penglihatan agar siswa dapat menyerap informasi secara optimal.

\section{b. Faktor Penyebab Kesulitan Secara Eksternal}

1) Penggunaan Media Pembelajaran

Guru kelas IV SD di Kabupaten Sintang sudah menyadari pentingnya media 
sebagai sarana untuk menyampaikan informasi agar siswa lebih mudah memahami materi yang diajarkan. Namun kendala yang ditemukan dilapangan yaitu kurangnya pemahaman guru terhadap media pembelajaran inovatif yang sesuai dengan materi, seperti guru belum menemukan media yang cocok untuk mengajarkan materi pecahan sehingga materi tersebut dijelaskan melalui analogi. Kurangnya pemahaman guru terhadap media pembelajaran inovatif berdampak pada kurangnya pemahaman konsep pada siswa karena tidak adanya contoh konkret yang membantu siswa untuk lebih mudah menerima materi.

Media yang digunakan guru adalah media yang sudah disediakan di sekolah. Dari paparan diatas dapat disimpulkan pentingnya penggunaan media dalam pembelajaran matematika. Oleh karena itu, guru hendaknya selalu menambah pengetahuan tentang media pembelajaran inovatif dan interaktif yang dapat digunakan untuk menambah motivasi siswa serta memudahkan siswa dalam menerima materi yang diajarkan.

2) Sarana dan Prasarana di Sekolah

Sarana dan prasarana di sekolah telah mendukung pembelajaran matematika. Kondisi bangunan dapat dikatakan baik karena gedung yang digunakan adalah bangunan permanen sehingga aman untuk belajar. Ruang kelas yang dilengkapi dengan ventilasi udara memungkinkan pertukaran udara sehingga kelas tidak pengap sehingga nyaman untuk belajar. Namun terdapat ruang kelas yang disekat yang mengakibatkan siswa kurang berkonsentrasi ketika kelas yang bersebelahan sedang ribut. Situasi belajar yang kurang baik seperti itu dapat memungkinkan pelajaran terhambat (Ahmadi dan Supriyono, 2013). Sekolah perlu mengkontrol fasilitas di ruang kelas seperti kelengkapan dan kelayakan kelas seperti membuat ruang kelas baru agar siswa tetap dapat belajar dengan nyaman.

3) Lingkungan Keluarga

Keluarga merupakan pusat pendidikan yang pertama bagi siswa. Bimbingan dari orang tua serta perhatian dari orang tua menjadi faktor penting dalam keberhasilan belajar siswa. Dari hasil analisis yang dilakukan diketahui siswa yang terindikasi kesulitan belajar matematika tidak selalu mendapat perhatian dari orang tua dirumah. Kurangnya perhatian dari orang tua disebabkan karena orang tua sibuk bekerja sehingga kurang memperhatikan pelajaran anak disekolah. Salah satu contoh kurangnya perhatian orang tua yaitu seringnya siswa tidak mengerjakan PR yang diberikan. Hal ini sesuai dengan penuturan Ahmadi dan Supriyono (2013) bahwa anak yang tidak mendapatkan pengawasan atau bimbingan dari orang tua kemungkinan akan banyak mengalami kesulitan belajar.

Hubungan yang baik antara orang tua dan siswa perlu dibangun agar orang tua senantiasa mengerti kebutuhan dan kesulitan yang dialami oleh siswa. Hubungan yang baik dapat dibangun dengan komunikasi dan meluangkan waktu serta mendampingi siswa 
dalam belajar. Selain itu, orang tua perlu berkomunikasi secara teratur dengan guru tentang perkembangan belajar anaknya disekolah sehingga kesulitan belajar yang dialami siswa dapat diatasi.

Berdasarkan teori dan hasil penelitian ditemukan proposisi bahwa faktor yang menyebabkan kesulitan belajar matematika terdiri dari faktor internal dan faktor eksternal, faktor internal meliputi sikap negatif siswa dalam belajar matematika, motivasi belajar siswa yang masih rendah, kesehatan tubuh yang tidak optimal, dan kemampuan pengindraan siswa yang kurang. Sedangkan faktor eksternal yang berasal dari luar siswa antara lain penggunaan media pembelajaran yang belum maksimal, sarana prasarana di sekolah, serta lingkungan keluarga.

\section{Upaya Mengatasi Kesulitan Belajar Matematika}

Setelah ditemukan kesulitan yang dialami siswa dan faktor-faktor yang menyebabkan kesulitan siswa, selanjutnya akan membahasan mengenai upaya mengatasi kesulitan belajar matematika. Analisis upaya mengatasi kesulitan belajar matematika kelas $\mathrm{V}$ di Kabupaten Sintang dilakukan dengan menganalisis hasil wawancara yang dilakukan pada guru kelas V. Dalam hal ini peneliti tidak melakukan upaya mengatasi kesulitan belajar matematika, namun peneliti menggambarkan upaya yang telah dilakukan serta memberikan saran untuk mengatasi kesulitan belajar matematika. Kesulitan belajar yang dialami siswa adalah kesulitan memahami konsep, kesulitan dalam keterampilan, dan kesulitan dalam memecahkan masalah. Sedangkan faktor yang menyebabkan kesulitan belajar matematika terdiri dari faktor internal meliputi sikap, motivasi, kesehatan tubuh, kemampuan pengindraan dan faktor eksternal meliputi, penggunaan media pembelajaran, sarana prasarana sekolah, dan lingkungan keluarga.

Untuk mengetahui upaya yang dapat dilakukan untuk mengatasi kesulitan belajar dijelaskan sebagai berikut.

a. Memperbanyak latihan soal

Salah satu kesulitan belajar matematika siswa adalah kesulitan dalam keterampilan dan kesulitan memecahkan masalah. Keterampilan dalam matematika adalah proses dalam menggunakan operasi dalam penjumlahan, pengurangan, perkalian, dan pembagian. Untuk mengatasi kesulitan dalam keterampilan dan memecahkan masalah perlu diperlukan latihan dan praktik yang terus-menerus. Hal ini mengacu pada Teori Thorndike yang menekan banyak memberi praktik dan latihan (drill and practice) kepada peserta didik agar konsep dan prosedur dapat mereka kuasai dengan baik (Muhsetyo, dkk. 2009). Untuk itu guru perlu memberikan latihan soal yang lebih banyak kepada siswa yang kesulitan belajar matematika karena dengan semakin banyak berlatih siswa akan semakin paham. Cara memberikan latihan soal yang lebih banyak pun tidak harus dilakukan di kelas, latihan soal bisa diberikan sebagai pekerjaan rumah untuk selanjutnya dipantau perkembangan kemampuan siswa.

b. Menggunakan Media Pembelajaran yang Konkret

Siswa sekolah dasar mengacu pada 
teori perkembangan kognitif Piaget berada pada tahap operasional kongret. Pada tahap tersebut siswa berpikir dengan apa yang dilihat atau benda konkret dan belum bisa berpikir abstrak. Untuk itu media pembelajaran yang konkret penting dihadirkan dalam pembelajaran matematika. Berdasarkan hasil analisis yang telah dilakukan guru tidak selalu menggunakan media pembelajaran yang kongret dalam pembelajaran sehingga siswa belum memahami dengan baik konsep yang diajarkan yang mengakibatkan siswa kesulitan dalam memahami konsep. Berdasarkan teori dan hasil penelitian ditemukan proposisi bahwa upaya yang dapat dilakukan untuk mengurangi kesulitan belajar matematika berdasarkan kesulitan yang dialami dan faktor yang melatarbelakangi antara lain menggunakan media pembelajaran yang konkret, memperbanyak latihan soal, dan menjalin kerja sama dengan orang tua siswa.

c. Menjalin Kerja Sama dengan Orang Tua Faktor internal penyebab kesulitan belajar matematika yang berasal dari siswa antara lain sikap, motivasi, kesehatan tubuh, dan kemampuan pengindraan. Berdasarkan hasil analisis yang telah dilakukan orang tua mempunyai peran penting dalam pemberian motivasi bagi siswa. Siswa yang diberi perhatian dengan baik dirumah akan mempunyai motivasi belajar yang baik disekolah. Untuk itu orang tua perlu senantiasa memberikan perhatian pada perkembangan belajar matematika siswa. Selain itu orang tua juga perlu memperhatikan pola makan dan jam istirahat siswa agar siswa mempunyai kondisi tubuh yang optimal dalam mengikuti pembelajaran matematika di sekolah.

Orang tua dan guru perlu bekerja sama meningkatkan motivasi siswa. Peningkatan motivasi siswa oleh guru dapat dilakukan dengan saran dari Gage dan Berliner (Slameto, 2010) sebagai berikut.

1) Pergunakan pujian verbal seperti mengucapkan kata "bagus", "baik" setelah siswa melakukan tingkah laku yang diinginkan merupakan pembangkit motivasi yang besar.

2) Pergunakan tes dalam nilai secara bijaksana yaitu memberikan informasi pada siswa dan untuk menilai penguasaan dan kemajuan siswa, bukan untuk menghukum atau membandingbandingkannya dengan siswa lain. Penyalahgunaan tes dan nilai akan mengakibatkan menurunnya keinginan siswa untuk berusaha dengan baik.

3) Bangkitkan rasa ingin tahu siswa dan keinginannya untuk mengadakan eksplorasi.

4) Pergunakan permainan yang melibatkan siswa secara langsung dalam proses pembelajaran. Berdasarkan teori dan hasil penelitian ditemukan proposisi bahwa upaya yang dapat dilakukan untuk mengurangi kesulitan belajar matematika berdasarkan kesulitan yang dialami dan faktor yang melatarbelakangi antara lain 
menggunakan media pembelajaran yang konkret, memperbanyak latihan soal, dan menjalin kerja sama dengan orang tua siswa.

\section{SIMPULAN (PENUTUP)}

Berdasarkan hasil penelitian dan pembahasan analisis kesulitan belajar matematika kelas V di Kabupaten Sintang diperoleh simpulan sebagai berikut:

1. Kesulitan belajar matematika yang dialami siswa terdiri dari tiga kompenen yaitu kesulitan memahami konsep, kesulitan dalam keterampilan, dan kesulitan memecahkan masalah.

2. Faktor yang menyebabkan kesulitan belajar matematika berasal dari faktor internal dan faktor eksternal. Faktor internal meliputi sikap siswa dalam belajar matematika, motivasi belajar siswa yang masih rendah, kesehatan tubuh yang tidak optimal, dan kemampuan pengindraan siswa yang kurang. Sedangkan faktor eksternal antara lain penggunaan media pembelajaran yang belum maksimal, sarana prasarana di sekolah, serta lingkungan keluarga.

3. Upaya yang dapat dilakukan guru untuk mengurangi kesulitan belajar matematika adalah dengan melakukan remidi pada materi yang belum dikuasai siswa.

4. Tingkat kesulitan belajar matematika siswa kelas V SD Negeri Rajang Begantung II termasuk dalam kategori sangat sulit.

\section{DAFTAR PUSTAKA}

Heruman, 2016. Model Pembelajaran Matematika di Sekolah Dasar. Bandung: PT Remaja Rosdakarya.

Jamal, Fakhrul. 2014. Analisis Kesulitan Belajar Siswa dalam Mata Pelajaran Matematika Pada Materi Peluang Kelas XI IPA SMA Muhamamadiyah Meulaboh Johan Pahlawan. Jurnal Pendidikan Matematika. 1(1).

Jamaris, Martini. 2015. Kesulitan Belajar: Perspektif, Asesmen, dan Penanggulangannya. Bogor: Ghalia Indonesia.

Mulyadi. 2010. Diagnosis Kesulitan Belajar \& Bimbingan Terhadap Kesulitan Belajar Khusus. Cet.II; Yogyakarta: Nuha Liter.

Slameto. 2010. Belajar dan Faktor-Faktor yang Mempengaruhinya. Jakarta: Rineka cipta.

Subini, Nini. 2012. Mengatasi Kesulitan Belajar Pada Anak. Jogjakarta: Javalitera.

Sugiyono. 2016. Metode Penelitian Pendidikan (Pendekatan Kuantitatif, Kualitatif, dan $R \& D)$. Bandung: Alfabeta.

Suryani, Melva. 2018. Pelaksanaan Bimbingan Belajar Dalam Mengatasi Kesulitan Belajar Siswa Kelas II Di SMA Negeri 5 Banda Aceh. Skripsi. Fakultas Tarbiyah dan Keguruan Universitas Islam Negeri (UIN) Ar-Raniry Darussalam Banda Aceh.

Tyas, Ni'mah Mulyaning. 2016. Analisis Faktor Penyebab Kesulitan Belajar Matematika Kelas IV Sekolah Dasar Negeri Di Kecamatan 
Ungaran Barat Kabupaten

Semarang. Skripsi. Jurusan

Pendidikan Guru Sekolah Dasar

Fakultas Ilmu Pendidikan

Universitas Negeri Semarang.

Utami, R. D; Wibowo, D. C.; Susanti, Y. 2018. Analisis Minat Membaca Siswa Pada Kelas Tinggi Di Sekolah Dasar Negeri 01 Belitang. Jurnal pendidikan dasar perkhasa,4(1):179-188, DOI: https://doi.org/10.31932/jpdp.v4i1. $\underline{22}$

Wibowo, D. C., \& Istiqomah, U. N. 2020. Solusi Pembelajaran Yang Menarik Untuk Guru Dalam Mengatasi Problematika Belajar Siswa di Kelas. Sintang: Yayasan Masyarakat Baik. 